Original Article

\title{
Islamic Spiritual Counseling Techniques
}

\author{
Muhammet Şerif KESKINOĞLU1® \\ Marmara University
}

\author{
Halil EKȘí1ْ \\ Marmara University
}

\begin{abstract}
In this study, some Islamic counseling techniques that can be used in psychology have been integrated into the spiritual counseling process. It is thought that introducing and starting to use spiritual counseling techniques based on Islam, would be beneficial to Islamic societies like Turkey. Transferring rich spiritual knowledge in Islam to the therapy process and approaching problem solutions by utilizing the client's spirituality can contribute to a more effective counseling process. A new point of view is aimed to be brought to spiritual consultants evaluating the values of spiritual counseling in the process of application of using sacred texts, pray, worship, contemplation, patience, gratitude, listening to hymn etc. It is aimed to transfer how they could use the techniques of spiritual counseling in the cultural sensitivity context into psychology consultants in their interventions to spirit. Also, practical interventions and empirical researches in spiritual counseling discussed with theoretical and ethical issues in the name of providing convenience to spiritual consultants. Results show the feasibility and utility of spiritual counseling techniques.
\end{abstract}

\section{Key Words}

Spirituality $\bullet$ Spiritual Counseling $\bullet$ Islamic Spiritual Counseling $\bullet$ Techniques $\bullet$ Psychology

\section{İslami Manevi Danıșmanlık Teknikleri}

$\ddot{O} \mathbf{z}$

Bu çalışmada psikolojik danışmada kullanılabilecek İslami bazı danışma tekniklerinin manevi danışmanlık sürecine entegrasyonu yapılmıştır. İslami yönelimli manevi danışma tekniklerinin tanıtılması ve kullanılmaya başlanmasının Türkiye gibi İslam toplumlarına faydalı olabileceği düşünülmektedir. İslam inancındaki zengin manevi birikimlerin terapi sürecine aktarılması danışanın maneviyatından yararlanarak sorunların çözümüne yaklaşılması daha etkin bir danışmanlık sürecine katkı sağlayabilir. Kutsal metinlerin kullanımı, Dua, ibadet, tefekkür, sabır, şükür, ilahi dinleme vb. tekniklerin uygulanış sürecinde manevi danışmanlığın unsurları değerlendirilmiş manevi danışmanlık yapacak psikolojik danışmanlara bakış açısı kazandırılmaya çalışılmıştır. Psikolojik danışmanların ruhsal olana yönelik müdahalelerinde, kültürel duyarlılıklar bağlamında manevi danışmanlık tekniklerini nasıl kullanabileceklerini aktarmak hedeflenmiştir. Ayrıca manevi danışmanlara kolaylık sağlayacağı düşüncesiyle manevi danışmanlıkta pratiğe yönelik müdahaleler, ampirik araştırmalar, teorik ve etik hususlarla birlikte ele alınmıştır. Elde edilen sonuçlar manevi danışmanlık tekniklerinin uygulanabilirliğini ve yararlılığını göstermektedir.

\section{Anahtar Kelimeler}

Maneviyat • Manevi Danışmanlık • İslami Manevi Danışma Teknikleri • Psikoloji

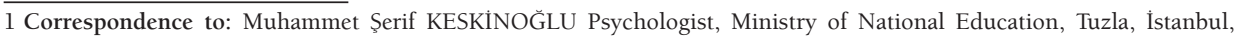
E-mail: serifbey@gmail.com

2 Department of Educational Sciences, Marmara University, Istanbul, Turkey. E-mail: halileksi@marmara.edu.tr

Citation: Keskinoğlu, M., \& Ekşi, H. (2019). Islamic spiritual counseling techniques. Spiritual Psychology and Counseling, 4, 333-350. http://dx.doi.org/10.37898/spc.2019.4.3.069 
The first serious approaches to spirituality in the history of modern psychology are seen in the, "transpersonal psychology" view led by Maslow's ideas, which emphasize the existential need of the individual who is a "transcendental and metaphysical" in aspect of religion and spirituality, and which aims to create the synthesis of Eastern science and Western science (Ekşi, Kaya and Çiftçi, 2016, s. 19). In addition, the hypothetic background of religious and spiritual approaches can said to be pastoral counseling, spiritual humanistic psychology and "Sufi psychology / mysticism psychology" which has a rich spiritual source in Turkey (Parlak, 2016). The spiritual psychological counseling abroad varies from traditional Christian (such as prayer and holy book interpretation) and Eastern (meditation, yoga) resources to existing counseling and psychotherapy forms, as well as directly developing religious and spiritual psychotherapy schools (Corveleyn and Luyten, 2013).

The researches conducted in the last decade indicates that when techniques related to spiritual counseling conducted in clinics used properly, they would affect positively the mental health and welfare of the clients. In addition, moral codes and application guides which emphasize the fact that the importance of knowing and respecting religious and spiritual diversity, are developed (American Counseling Association, 2005; American Psychological Association, 2010). Lots of mental health specialist find interventions based on spirituality beneficial (Post \& Wade, 2009; Walker, Gorsuch, Tan and Otis, 2008). It has been indicated that spiritual interventions are more effective compared to secular interventions (Smith, Bartz and Richards, 2007). Lots of research results on this topic and techniques developed by using religious and spiritual resources are published (Aten \& Leach, 2009; Moodley \& West, 2005; Pargament, 2007; Plante, 2009; Sperry \& Shafranske, 2004). It has been emphasized in these researches that spirituality is one of the strategies that used in one's rehabilitation and problem-solving. In this aspect Pargament (2007), indicates that therapists should examine more than one-factor deciding clients' psychology. Among these factors, acknowledging the divine extent of clients' life and taking it into consideration is thought to be one of the features that makes therapy effective and brings the client and therapist together.

\section{Islamic Spiritual Counseling Techniques}

According to Pargament, religion has five fundamental aims like; meaning one's problem-solving process, giving control and confidence, consoling, providing intimacy and social support and contributing transformation process Pargament, 1997, s. 190-240; Pargament, vd., 2000). The references in religious coping are religious practices based on sacred existence and religious beliefs such as prayer and worship (Koç, 2008, s.72). Islam offers to its believers a rich spiritual accumulation. There have been lots of Islamic scholars around since from the birth of it till today and they 
have taken the role of educator in society. They have developed educatory methods intended to know individuals and support them and they have tried to explain the individual.

Spiritual individuals who have more proper mental and physical functions are tended to think positively, and they generally do not attempt to harm themselves (Thoreen, 2007). While Koenig indicates the fact that individuals who have strong spirituality have adopted a more healthy life, tended to have social support and generally not busy within destructive patterns, and they have better mental health functions like mental status and emotion control than others (Koenig vd, 2001), according to Plate (2009) spirituality and religion give positive results for one's psychologic health and welfare.

In a study conducted in Sweden (DeMarinis 2003, p.91), 82\% of the most frequently discussed subjects in the spiritual counseling process are grief and $67 \%$ with family-related problems. Others are indicated in orderly; pain and loneliness $67 \%$, fear-anxiety $57 \%$; difference and conflicts $55 \%$. There are researchers conducted in compulsive disorientations and depressions used in programs in Christianity belief (Hawkins, Tan, \& Turk, 1999; Johnson, Devries, Ridley, Pettorini, \& Peterson, 1994; Pécheur Se Edwards, 1984; Propst, Ostrom, Watkins, Dean, \&Mashburn, 1992). Results of this research show that applicability and benefits of religious counseling techniques. Some counseling techniques that can be used in therapy and guided to clients be are given below.

\section{Religious Attitudes and Rituals}

Believing in God gives inner peace and confidence to spiritually depressed patients (Link, 2000). Religion and its worship aspect give meaning to life, help bearing pains like death, sickness and injury that affect the mental health of individuals a great deal, refresh hope of living and give force to handle all difficulties in life (Hökelekli, 2002, p. 126). According to Holden and Williamson (2014), religion in the family has a positive relationship with psychological health and welfare of child and teen. In addition, it is known to be effective in decreasing the aggressiveness degree of the teen.

McCullough and Larson analyzed 80 empiric researches that have been published and unpublished dealing with relationship between religious indicators which are defined by "devotion to a certain religion", "religious interest", "religious beliefs", "attending religious worships", "prayers", "introvert and extrovert religious motivation" with depression signs and defects. Results show that individuals who have lots of religious bonds, worships and high introvert religious points have lesser depression signs and defects (McCullough and Larson, 1999, p.126-136). Sohail (2018) indicates that they have used religious and spiritual belief (especially worships 
and beliefs have provided emotional satisfaction in patients) in order to ease pains of the patients and struggle with diseases in studies with Muslim chronic liver patients. The patients who use religious and spiritual beliefs can focus on positive aspects by purifying their minds from pains.

Smith, McCullough and Poll who examine the relationship between religion and depressive symptoms by meta-analyze technique, discovered the fact that there is an opposite relationship between religion and depression symptoms (Smith, McCullough and J. Poll, 2003:614-636). In addition, results meaning the group which underwent application of cognitive-behavioristic therapy that integrated with Islamic beliefs recover faster than the control group (Azhar and Varma, 2000). Şengül, (2007) detected the meaningful negative relationship between wisdom aspect of religion and depression. Results show that when the wisdom aspect of religion is increased, depressive symptoms are decreased, and the religion, especially carrying out worships could have a protective function against depression.

The prayer which is repeated during the day in Islam, provides relief and relaxation even for a short time by enabling one to clear his head from daily life choirs, problems troubling his mind. It provides a mental discharge. As the prayer continues within certain time periods, after some time one can get rid of thoughts damages his mental health completely (Peker, 2010, p.206). It reinforces religious aspects against some psychological situations, provides a positive point of view and affect positively to strength for difficulties. The prayer supports clients' positive attitudes and behaviors towards their worships as a spiritual counseling technique. It can be indicated that worships have a relaxing effect. Positive effects can be said behaviors like donations to charities, cooperation between individuals, gifting etc. Moreover, socializing and relaxing effects of some cooperative worships can be said.

\section{Pray}

Pray is seen as one of the cognitive coping strategies as it provides reinterpretation and acknowledging of events and situations (Arıc1, 2015, p.84). It has seen not only religious people pray, but also people who lost their faith and choose a rational lifestyle to pray too (Marrinier, 1991). Pray is the way people reveal their emotions, reactions, wishes and needs (Argyle, 2016). Spirituality is an emotion unique to mankind. It is the wish for making a divine connection and feeling close to sacred. It has been uttered that this feeling is universal. This feeling is accepted as important as it is known for having a mysterious way of understanding mankind.

Although pray is one of the rehabilitation techniques that has been used since ancient times, begin a topic for scientific researches is recent. Pray, lately, has been examined by lots of theologians and philosophers in different ways (Marrinier, 1991; Mckinney, vd.1999). 
Weld and Eriksen (2007) found in their research that Christian clients examined pray expectations regarding prayer: (a) $82 \%$ of clients asked for voice prays at counseling, (b) therapists chose the content of pray, and (c) they have strong expectations that the pray was included in counseling. $40 \%$ of those living in the UK that more than $60 \%$ of people living in the United States pray daily, while $90 \%$ say they pray sometimes. Some of these said that they prayed three times in a day or more. The psychological and psychotherapeutic effects of pray on the individual were examined in the field study called "Psychological and Psychotherapeutic Effects of Prayer" by Doğan (1999). At the end of the survey conducted with different age groups belong to different developmental stages in three different providence of Turkey, it can be concluded that pray has psychological rehabilitation effects on individuals. Pray which is defined as demanding for oneself or others to God, has the strongest effects of cognitive symptoms of depression (Weld and Eriksen, 2007). It can be said that pray overlaps with purposes of cognitive therapy (Corey, 2005). Relaxing by praying can be shown to the clients by applying. So, it is not a surprise to witnessing the patients and their relatives approve consultant saying, "I will pray for you" (Taylor, 2003). Although theoreticians have asserted clinical claims about therapeutic benefits of praying (Butler, Stout \& Gardner, 2002; Fincham, Beach, Lambert, Stillman and Braithwaite, 2008; Heck, 2006; Koenig and Pritchett, 1998), the effect of praying generally ignored (Robinson, 1994; Butler vd. 2002). According to some researches, the praying rate of teens who claim their interest in religious institutions is approximately $87 \%$ (Janssen, 1990). Tan (2007), used sacred texts in Christian Cognitive Behavioral Therapy (CBT). Fatemi (2018) indicates that during the therapy process, Muslim clients saying "salavat" and praying were effective in solving clients' problems. Khan, Mughal and Khan (2013) found that religious intervention techniques that are compatible with psychological intervention techniques have contributed to the emotional improvement of the clients in their study that they have conducted with university students.

The spiritual consultant can use praying as an icebreaker to have deep communication with the patient and have a therapeutic relationship with the client (Taylor, 2003). The most important benefit of praying is that one would know he is not alone. Because who prays, have fewer anxieties about the future, doesn't look pessimistically to life and have good expectations (Peker, 2010, p.197). In this context, the clients can support approaches related to possible praying in their therapy process. As a result, thinking methods like; thinking over situations, cognitive discussion, interpreting and making connections between thoughts are taught to the clients. In this context, the client whose mind undergoes a reconstruction process by contemplating and fully consecrating on an event or a situation with the help of praying, gains an insight of his own problems and achieves the reconstruction. In collective praying, one feels that he is not alone and steers to a positive rehabilitation. 


\section{Spiritual Bibliotherapy}

In psychotherapy, usage of sacred texts named as "spiritual bibliotherapy"(Frame, 2003, p. 190), "religious bibliotherapy" and "pointing to religious texts" (Koenig \& Pritchett, 1998. p. 329). Frame (2003), defined this intervention in therapy as "using books, stories, myths or spiritual themes with other literature". Tan (1996), a therapist only considers the sacred texts at the request of the counselor and generally focuses on the feelings and perceptions of the client rather than trying to interpret or study the sacred texts in detail. According to Şengül (2002, p.25/501), generally in the parables of the Qur'an issues like; increasing resistance force of Muslims and Prophet against problems, consolidating them, encourage them to praying, patience and trust, reminding blessings of the God and forbidding them from the devil are referred. Arac1 (2007) "Individuals who participate in bibliotherapy conducted by using Sufi parables have more self-achieving points than individuals who don't participate such therapies" and "It has been found that individuals who participate in bibliotherapy decrease their non-functional behaviors, and their self-achieving tendencies are increased".

It is important to a therapist functions as a mental health professional and doesn't use this role as a reverend while dealing with sacred texts in a therapy (Miller, 2003; Pargament, 2007; West 2000). Malik (2008) tried to use systematical family therapy by utilizing parables from the Quran in his doctorate thesis. It is to build bridges by considering the possible tension issues between Western psychotherapies and Islam and to make an integration study in psychotherapy. Hz. Ibrahim and Hz. Ismail's Qur'an narrative has been used to solve the problems in a mother and son relationship.

\section{Reading the parables of the Qur'an}

It is possible that education method with the parables and stories make one to know the art spirit of beauty, increase the thinning sensitivity, improve spiritual world and contemplation about the universe, hold up as an example from hadiths, search the divine and guide to ideas of avoiding perversity (Kutub, 1975, p.17). According to Atalay (2012, p.175), Qur'an parables are instructive in terms of their leading qualities. However, Qur'an parables that provide "wisdom, clairvoyance and guidance" in any part of the history, is the top example of written heritage in mankind's hands. It is important to adapt parables into today's conditions.

Lots of researches have been conducted and the bibliotherapy is applied in topics like; understanding and acknowledging individual differences in children and teens (Gavigan \& Kurtts, 2011); treatment of panic attacks (Febbraro, 2005); losing weights (Hagen, 1974), in treatment of curtail step health services and depression treatments (Naylor vd., 2010); teaching students to solve problems they encounter in daily life (Forgan, 2002); on patients that are being treated in the hospitals (McMillen\& Pehrsson, 
20004); families that anxiety problem in their children (Rapee, Abbott, Lyneham; 2006), helping students to learn to cope with stress, anxiety, grieving (Cook\& EarlesVollrath\& Ganz, 2006); treatment of loss and grief (Briggs\&Pehresson, 2008); to understand the difficulties faced by separation, divorce, child abuse, adoption, relocation, death, disease and disabled individuals (Cook\& Earles-Vollrath\& Ganz, 2006), defect of sexual functions (Van Lankveld, 1998). McCullis (2012) indicates that the bibliotherapy is an effective and efficient tool in therapeutic devices and reinforce therapy. Murooff vd. (2012) indicates that bibliotherapy can be used in basic health services and psychoeducation; McKenna, Hevey \& Martin (2010) indicates that constructed materials can decrease sadness. If a therapist thinks it is unhealthy that a client understands a sacred text, the therapist should make the client apply for a spiritual authority rather than facing with theological issues.

In this context, it can be said that reading Qur'an both in the original language and in Turkish translation has a relieving effect on individuals who have psychological problems. When a profound and rich meaning of Qur'an is considered, it can be used as a therapeutic technique. These parables can either be evaluated or just read.

\section{The Role Modeling}

Another spiritual technique is role modeling. Role modeling is one of the important aspects that provides social learning. There are numerous role models throughout the history (Oman and Thoresen, 2003, p.2007). Religious role models like; Hz. Muhammed (SAV), Hz.Isa and Buda; role models like; Ganhdi, Mother Teresa, Dalai Lamai Martin Luther King can be examples for clients. The Prophet, Hz. Muhammed (SAV) carried out spiritual- religious counseling in his twenty-three years prophet life. He transformed the principles of Qur'an: remedy to hearts (Fussilet, 41/44; Yunus, 10/57; İsra,17/82), life givers to hearts (Şura, 42/52) into his life. Then he made a great chance on the society by placing these facts into his followers' life.

Our beloved prophet Hz.Muhammed (SAV) used kind wording and tolerance, he grounded on gradualism by observing the ones before him, embraced convenience principle, gave hope by heralding, embraced the question-answer method. He used "adage, depiction and parable" in order to place some topics to the minds (Çetin, 2008:228-295). Issues like; being orphan by birth, losing his mother at the very beginning of his life, treated badly by some of his relatives, immigrate to another place for the sake of his beliefs, his marriage, his children, pains he suffered, and his losses can be example to make him a role model. Hz. Muhammed's (SAV) life can be related and can provide improving insight. 


\section{Patience}

Patience meaning bearing difficulties like losses, is a term which has cognitive, emotional and behavioral dimensions (Doğan, 2017, p.270). "Patience is bearing, resisting, opposing and coping to get over pain, suffering and problems." (Işı1k, 2013). In this respect, it is the phenomenon of consenting events that give strength. Patience teaches being mature by providing one to reach his aim and protect it. Patience is power to the present situation and proceeding without deviation on the way saving power to upcoming.

\section{Submission}

Submission is the natural outcome of devotion to the God and believing in fate. Coping with sad and troubling problems in life by applying submission is another religious way of dealing with problems (Iş1k, 2013). Believers can grace because of events they have gone through. One is usually tended to grace when he sees a person in a worse situation than him (Ayten, 2012, p. 45). The ones who believe in the submission are more powerful. They don't get upset against the ups and downs of life (Demirci, 2009, p. 69). Submission cannot be observed by outside. It shapes in one's inner world. It can be thought that submission has a critical effect when one is against difficulties and exposure to stress. Submission is leaving the fate to the God after doing what is necessary. In this respect, it forms a frame of mind that makes one powerful and positive. It can be beneficial to use this frame of mind in coping with clients' problems. In this technique, the therapist, after talking the cognitive side of submission, wants the client to note down submission moments he would have until the next meeting. In the next meeting positive effects of these moments on the client would be evaluated.

\section{Grace}

Grace is knowing and accepting verbally the fact that every blessing is from the God. Carrying out the commands and avoiding the prohibitions of is gracing. In this respect, the source of quietude is accepting what you have got. Quietude is achieved by being aware of you have rather than being sad for what you don't have. Mostly, modern people of the era complain without being aware of what they have got and always ask for things they wouldn't probably reach. Grace is a shaped version of these wishes (https://islamansiklopedisi.org.tr/sukur). In this respect during the counseling process awareness of patience, submission and grace should be brought in to the clients. As it is known that grace which is underlined frequently in the basis of Islamic thinking system, is one of the coping techniques, this topic can be taken into consideration and people's views can be improved in this way to provide maximum benefit in the therapeutic process. 


\section{Penitence}

The clients regret strongly from their past behaviors as they were inappropriate (Meadow and Kahoe 1984:417). "Penitence" and "praying for forgiveness (istiğfar)" can be used as counseling techniques for Muslim clients in counseling applications based on Islamic principles (Şirin, 2013). "Penitence" which means giving up disturbing thoughts, feelings and behaviors that one can define as mistake and sin without turning back is the beginning stage of psycho-therapeutic rehabilitation in terms of starting of self-awareness and taking actions. Also, this forms a positive motivation resource. As a result, the best remedy for unwanted situations like stress and anxiety which are arisen from behaving wrong, is "Penitence". So, when religious counseling process supports this process positively, a new construction process in the client's mind is started. In short "Penitence" which is an effective technique with its "cognitive reconstructive, treatment etc." meanings stand out as a concept that can be an active and intervention technique in "CBPAIRCM (Cognitive Behavioral Psychotherapy Integrated with Religious Counseling Model) (Şirin, 2013).

\section{The Gifting Technique}

Gifting is important in Islam. It has been emphasized that gifting arranges relationships and forms lovely bonds. In this technique, the consultant wants, after developing a point of view in the concept "gifting", the client to give a gift to the person he is having trouble with or person he chooses to in a week in the aim of using the positive effect of gifting on people. In the next session, the client evaluates the effects of this study on himself and the person to whom he gave the gift. This is a technique that can provide benefits in relationships that have mutual troubles. It can be used frequently in family therapies.

\section{Forgiving Yourself and Others}

In the forgiving technique, spiritual and religious beliefs of the clients are utilized to enable them to forgive themselves and others. Lots of traditions offer forgiving yourself and others and some people feel themselves close to their high powers when they forgive (Barrera vd, 2012). Religion and spirituality invite people to forgive, to be grateful, affectionate, kind and merciful. For example, researches proved the positive sides of being forgiven (Koenig vd, 2012). Forgiving is an antidote for anger, hostility and pains. Researches show that people with strong spirituality are more optimistic, more energetic and have more decent interpersonal relationships (Emmons and McCullough, 2003). Although forgiving is a personal concept free from any kind of religion or spirituality, there is a close relationship between forgiving and spirituality for lots of people. 
The consultor can ask questions to the clients like; "Is forgiving suits for your religion/ spiritual values?", "Is this suitable for your religion/ spiritual values?" regarding "Forgiving yourself and accepting yourself" (Barrera vd, 2012). Islamic point of view is forgiving. The importance of being forgiver can be taken into consideration as a counseling technique in the counseling process.

\section{Contemplation}

The most important motivation in the life is believing in the existence of the God (Alper, 2002, p. 155). Religion and the God are the most important resource of hope and sanctuary in situations like; meeting desires on any condition such as one's fears, doubts, inability, desperations, loneliness, privacy, failures, disappointments, hates, and other desires on situations like sinning, suffering, feeling of being guilty, regrets, disappointments, pains and injustice (Günay, 2010, p. 417). People need a mighty supernatural being who can help them and to whom they can shelter when they encounter events and situations they couldn't handle and make them feel powerless and desperate (Certel, 2011, p.111). In this respect, people who have developed contemplation ability, can give their life meaning by understanding the universe and diversifying their point of views in terms of arranging relationships among people.

\section{The Search of Meaning with Halal and Illicit in Islam}

While forming value judgments, beliefs also shape the behaviors of people. Some behaviors of people may because of religious references. The thoughts and beliefs behind people tried to be detected by evaluating one's characteristic reflected to psychotherapy and misbehaviors and their perceptions with the help of the pursuit of meaning.

Islam strictly forbids alcohol consumption, and this can be a remarkable issue to Muslims, especially to immigrant Muslims who lives in western countries (Al1, Allmon and Cornıck, 2011). Ali vd. (2004), states that high school and university students can be very sensitive to consuming alcohol and peer pressure. This reveals the need for spiritual counseling in understanding the reasons of one's behaviors.

Sometimes, counseling the clients to reverends and religious leaders can be helpful in solving disputes. These kinds of counseling can be beneficial as the clients approve religion, especially when they expect more negative implications (Aten, 2011). Duba and Watts (2009) state that religious beliefs can affect sexual roles of couples, forgiveness of marriages, parental responsibilities and thoughts about old parent care.

\section{The Technique of Dream Interpretation}

According to Jung, the most important carrier of non-conscious reactions to one's psychic dilemmas is dreams. Concentration in the process of spiritually focused 
psychotherapies should firstly tend to the dreams (Çetin, 2010). What is wanted to be achieved in Jung's spiritual focused dream interpretation technique is meaning the endless variation of dreams that include visuals, symbols and writings in it with the clients (Jung, 2001).

Dream interpreting is mentioned in Islamic resources. The positive interpretation of dreams can be a relieving element to the clients. Dreams are the reality of life and part of living. Clients who have problems could frequently see dreams and nightmares, and they need to interpret these dreams and nightmares to be relieved. In this respect, dream interpretation can be used as a spiritual counseling technique. To be able to interpret dreams, one needs to be proficient in this matter. The most important aspect in dream interpretations, interpreting dreams in a positive way and encourage clients to this way.

\section{Hymns}

Music appeals to people of all ages. It helps to share inner peace and inner edginess, helps to inner equilibrium, it serves people to make them sensitive, happy and as a result of these make them successful. So, the personal function of music serves people to overcome emotional problems and creating positive emotions rather than negative ones by training and improvement of emotions related to psychological side of them, easing the anger, sharing the sadness etc. (Uçan, 2004, p. 5). Hymns are the most used and brightest form of religious Turkish music (Özalp, 2000, p.1111).

Cevasso vd. (2005), reached the fact that musical therapy is effective on anxiety, depression and movement activity with drug-addicted females. Sezer (2011) found out through researches that music has both positive and negative effects on people. This finding shows that using music for people's mental health would have beneficial results. For this purpose, it would be beneficial to listening to, popularizing and guiding our teens to the music types that have a positive effect on anger and psychological issues. In this context, a hymn which is a music type is thought to be helpful to the clients in coping with stress.

\section{What Should Be the Role of the Therapist?}

The therapist can't guide the clients to religious or spiritual ways with suggestions he would make insight of his own thoughts (Corveleyn and Luyten, 2013). The therapist should avoid affecting clients' religious thoughts and discussion spiritually that isn't related to the therapy (Shanfranske, 2009). The ethical principles for the therapist include most of the principles that are presented by religious and spiritual traditions. These are respect, responsibility, honesty, proficiency and concern towards others (Plante, 2004). Bartoli (2001), detected that an analyst evaluating religion with 
a minimalist approach, couldn't differentiate spiritual aspect, brought by a client who has a high religious and spiritual side, in religious content from psychological content. These reasons recons that an analyst who is tended to spirituality in person can differentiate between psychological and spiritual aspects brought by clients better and use spirituality better. The APA politics explains that "psychologist can talk about the psychological effects of religious/ spiritual applications, when there is finding in these matters." So, the positive effects of spiritual related psychotherapy should be conveyed to the clients. It is stated that therapy will be implemented in accordance with ethical principles and that respect for beliefs and it is one of the ethical first in determining and applying these techniques (Hathaway, 2011).

\section{Results}

In this study, some of the Islamic spiritual counseling techniques that can be used in psychological counseling are explained. The use of sacred texts, and in the process of implementation of the techniques like; prayer, worship, contemplation, patience, grace, contemplation, gifting, role modeling, hymns etc., the elements of spiritual counseling have been tried to gain perspective on psychological counselors who will evaluate the spiritual counseling.In basic psychotherapy, mostly spirituality can be neglected.However, the effect of spiritual therapy on people has been confirmed by many studies. (Aten \& Leach, 2009; Moodley \& West, 2005; Pargament, 2007; Plante, 2009; Post \& Wade, 2009; Sperry \& Shafranske, 2004; Smith, Bartz \& Richards, 2007; Walker, Gorsuch, Tan, \& Otis, 2008;). Using this sensation in the solution of the problems by taking advantage of the spiritual approaches of people can be evaluated as a technique that will lead the therapeutic process to success.It has been stated that love experiences of people have led to serious changes in their lives. Spirituality is a unique emotion to mankind. It is the desire to contact the sacred one and be close to him. Islam offers a rich spiritual accumulation to its followers. There have been lots of Islamic scholars around since from the birth of it till today and they have taken the role of educator in society. They have developed educatory methods intended to know individuals and support them and they have tried to explain the individual. Lots of researches have been conducted proving that Islamic spiritual counseling techniques are beneficial (Arac1 (2007; Azhar and Varma, 2000; Çetin, 2008; Doğan, 2007; Fatemi, 2018; Malik, 2018; Şengül, 2002).

The sacred book and spiritual resources like prayer have become accepted concepts in clinical counseling and psychotherapy (Hawkins, Tan, \& Turk, 1999; Johnson, Devries, Ridley, Pettorini, \& Peterson, 1994; Pécheur Se Edwards, 1984; Propst, Ostrom, Watkins, Dean, \&Mashburn, 1992). Prayer is used during sessions and homework given to the clients after sessions. As praying is for the almighty God, it is used in case of loss of a loved one, feeling of desperation and serious 
problems, and positive outcomes can be taken. Moreover, being in spiritual contexts, utilizing from group activities, committing social help as a reliever can thought to be other kinds of homework. It increases worship resistance to some psychological situations and can have a positive effect on the power of coping with difficulties in ensuring that the person looks positive to life.Positive attitudes and behaviors of the clients towards worship can be supported as the spiritual counseling technique. It can be stated that worships have relieving effects. Positive effects of donation to charities and helping can be observed. Moreover, socializing and relaxing effects of some cooperative worships can be said. Apart from this, listening to hymns, which are a type of religious music, can be relieving and comforting. With the help of contemplation, patience and gratitude intellectual skills, the client's coping strategies can be developed.

The basic element of therapy is patience. The spiritual experiences of the clients are respected. Applications should be according to spiritual cooperation and balancing. To be able to conduct spiritual counseling, the therapist should believe in these techniques, have experiences, and have enough proficiency. It is also necessary for the therapist's positive approaches to give confidence to the client and to support him and to share his spiritual experiences. The closeness of the therapy process to the client is only possible by touching his cultural point of view. It is known that the problems with religion originate from the subjective lives of people.The therapy process should be nutritious to the spirit of the client. In this respect, it is thought that using Islamic spiritual techniques in Islamic societies is beneficial.

\section{References}

Aracı, U. (2007). Sûfî hikâyelerinin kullanıldı̆̆ı̆, bilişsel-davranışçı yaklaşımla bütünleştirilmiş biblioterapinin işlevsel olmayan düşünceler ve kendini gerçekleştirme üzerindeki etkisi. (Yüksek lisans tezi, Ankara Üniversitesi Eğitim Bilimleri Enstitüsü, Ankara). https://tez.yok. gov.tr/UlusalTezMerkezi/ adresinden edinilmiştir.

Alı, S. R, Allmon, A. And Cornick, C. (2011). Value Clarification Spirtually Oriented Intervention for Counseling and Psychotberapy (Aten, J. D., McMinn, M. R., Worthıngton, E. L.) Washington, DC American Psychological Association APA Order Department

Ali, S. R., Liu, W. M., \&. Humedian, M. (2004). İslam 101: Understanding the reli- gion and therapy implications. Professional Psychology, Research and Practice, 35, 635-642. http:// dx.doi.org/10.1037/0735-7028.35.6.635

Alper, H. (2002). İmanın psikolojik yapısı., İstanbul: Rağbet Yayınları.

American Counseling Association. (2005). Code of ethics and standards of practice. Alexandria, VA: Author.

American Psychological Association. (2010). Ethical principles of psychologists and code of conduct (2002, Amended June 1, 2010). Retrieved from http://www. apa.org/ethics/code/index. aspx 
American Psychological Association (2008). Resolution on religious, religion'based, and/or religion-derived prejudice. American Psychologist, 63, 431-434 https://www.apa.org > religiousdiscrimination

Argyle, M. (2006). İbadet ve dua (M. Koç, Çev.), Sosyal Bilimler Enstitüsü Dergisi, 2 (21) 329-335.

Arıc1, A. (2005). Ergenlerde dinî başa çıkma yöntemi olarak dua. (Yüksek lisans tezi, Uludağ Üniversitesi Sosyal Bilimler Enstitüsü, Bursa). https://tez.yok.gov.tr/UlusalTezMerkezi/ adresinden edinilmiştir.

Atalay, M. (2011). Dinsel metin okuyarak psikolojik zorluklarla başa çıkmak: bibliyoterapinin kapsamını genişletmek. Ekev Akademi Dergisi, 48, 23-52.

Aten, J.,\& Leach, M. (Eds.). (2009). Spirituality and the therapeutic process: A com- prehensive resource from intake through termination. Washington, DC: American Psychological Association.

Aten, J. (2011). The college campus ministry training site: Interfacing religion and counseling. Counseling and Values, 49, 64-68. https://doi.org/10.1002/j.2161-007X.2004.tb00253.x

Ayten, A. (2012). Tanrı "ya sığınmak: dini başa çıkma üzerine psiko-sosyal bir araştırma. İstanbul: İz Yayıncilık.

Azhar, M. Z.,\& Varma, S. L. (1995). Religious psychotherapy as management of bereavement Acta Psychiatrica Scandinavica, 91(4), 233-235. https://doi.org/10.1111/j.1600-0447.1995. tb09774.x

Barrera, T. L., Zeno, D., Bush, A. L., Barber, C. R., \& Stanley, M. A. (2012). Integrating religion and spirituality into treatment for late-life anxiety: Three case studies. Cognitive and Behavioral Practice, 19(2), 346-358 https://doi.org/10.1016/j.cbpra.2011.05.007

Bartoli, E. (2001). Psychoanalytic practice and the religious patient: Thepolitics ofagency and responsibility (Doctoral dissertation, The University of Chicago). Retrieved from http:// search. proquest.com/docview/304739235 ?accountid=12251.

Butler, M. H., Stout, J. A. \& Gardner, B. C. (2002). Prayer as a conflict resolution ritual: Clinical implications of religious couples' report of relationship softening, healing perspective, and change responsibility. The American Journal of Family Therapy, 30, 19-37. https://doi. org/10.1080/019261802753455624

Certel, H. (2011). Din psikolojisi, Isparta: Tuğra Ofset.

Cevasco, A. ve Diğerleri (2005). Comparison of movement-to-music, rhythm activities, and competitive games on depression, stress, anxiety, and anger of females in substance abuse rehabilitation, Journal Of Music Therapy, 42 (1): 64-80. https://doi.org/10.1093/jmt/42.1.64

Cook, K. E., Earles-Vollrath, T., \& Ganz, J. B. (2006). Bibliotherapy. Intervention In School And Clinic. C. 42, 2, 91-100. http://dx.doi.org/10.1177/10534512060420020801.

Corey, G. (2005). Psikolojik danışma, psikoterapi kuram ve uygulamaları (7. bask1). Ankara: Mentis Yayınları.

Corveleyn, J. ve Luyten, P. (2013). Psikodinamik psikolojiler ve din: Geçmiş, günümüz ve gelecek, (F. Kıraç, Çev.). Paloutzian, R. E ve Park, C. L., (Ed.), Din ve maneviyat psikolojisi, temel yaklaşımlar ve ilgi alanları içinde (s. 169-206). Ankara: Phoenix Yayınları.

Çetin, A., (2008). Hitabet ve irşat din hizmetlerinde iletişim ve güzel konuşma (Genişletilmiş 2. Bask1). Bursa: Emin.

DeMarinis, Valerie (2003). Pastoral care existential health and existential epidemiology a swedish postmodern case study. Upsala University, Stockholm. 
Demirci, M. (2009). Hadislerle tasavvuf kültürü. İstanbul: Vefa Yayınları,

Doğan, M. (2017). Dindarlık, sabır ve psikolojik iyi oluş arasındaki ilişkiler üzerine bir araştırma. H. Hökelekli (Ed.), Din, Değerler ve Sağlık içinde (s. 265-306). İstanbul: Değerler Eğitimi Merkezi Yayınları.

Doğan, M. (1997). Duanın psikolojik ve psikoterapik etkileri. (Yüksek lisans tezi, Uludağ Üniversitesi, Sosyal Bilimler Enstitüsü, Bursa). https://tez.yok.gov.tr/UlusalTezMerkezi/ adresinden edinilmiştir.

Duba, J. D.,\& Watts, R. E. (2009). Therapy with religious couples. Journal of Clinical Psychology, 65, 210-223. http://dx.doi.org/10.1002/jclp.20567

Ekşi, H. \& Kaya, Ç. \& Çiftçi, M. (2016). Maneviyat ve psikolojik danışma. [içinde] H. Ekşi \& Ç. Kaya (ed.), Manevi yönelimli psikoterapi ve psikolojik danışma (ss. 13-28). İstanbul: Kaknüs Yayınları.

Emmons, R. A.,\& McCullough, M. E. (2003). Counting blessings versus burdens: Experimental studies of gratitude and subjective well-being. Journal of Personality and Social Psychology, 84, 377-389. http://dx.doi.org/10.1037/0022-3514.84.2.377

Fatemi, S.M. (2018). Integrating dua arafa and other shiite teachings into psychotherapy. In Al Karam,Y.C. (Eds.), Islamically Integrated Psychotherapy (pp.229-242).PA:Templeton Press

Febbraro, A. R. G. (2005). An Investigation Into the Effectiveness of Bibliotherapy and Minimal Contact Interventions in the Treatment of Panic Attacks. Journal Of Clinical Psychology, 61, 6, 763-779. http://dx.doi.org/10.1002/jclp.20097.

Fincham, F. D., Beach, S. R. H., Lambert, N., Stillman, T., \& Braithwaite, S. (2008). Spiritual behaviors and relationship satisfaction: A critical analysis of the role of prayer. Journal of Social and Clinical Psychology, 27(4), 362-388. https://doi.org/10.1521/jscp.2008.27.4.362

Flaxman, P. (2010). An introductory guide to mindful- ness skills. promoting the psychological well-being ofNHS Staff (Rapor), Svvindon: Economic and Social Research Council (ESRC).

Forgan, J. W. (2002). Using bibliotherapy to teach problem solving. Intervention In School And Clinic, 38(2), 75-82. https://doi.org/10.1177/10534512020380020201.

Frame, M. W. (2003). Integrating religion and spirituality into counseling: A comp sive approach. Pacific Grove, CA: Brooks/Cole.

Gavigan K. W. \& Kurtts S. (2011). Using Children's and Young Adult Literature in Teaching Acceptance and Understanding of Individual Differences. The Delta Kappa Gamma Bulletin, 77(2), 11-16. Retrieved from http://www.dkg.org

Günay, Ü. (2010). Din sosyolojisi. İstanbul: İnsan Yayınları,

Hagen, L. R. (1974). Group therapy versus bibliotherapy in weight reduction. Behavior Therapy, $5,222-234$.

Hathaway, W. L. (2011). Ethical guidelines for using spiritually oriented interventions spiritually orlented intervention for counseling and psychotberapy. Washington, DC American Psychological Association APA Order Department

Hawkins, R.S., S.Y. Tan and A.A. Turk, (1999). Secular versus Christian inpatient cognitive behavioral therapy programs: Impact on depression and spiritual well-being, Journal of Psychology and Theology, 27, 309-331. https://doi.org/10.1177/009164719902700403

Heck, T. A. (2006). Sacred healing of marriage: A quasi-experimental study of prayer's effect on marital satisfaction among catholic and protestant Christians. (Doctoral dissertation, Capella Univerity, 2006). Dissertation Abstracts International, 67(1), 599B. (UMI No. 3206555); 
Holden, W.H. and Williamson, A.P.(2014). Religion and child well-being. Handbook of child well being, 1137-1169

https://islamansiklopedisi.org.tr/sukur(14.09.20019).

Işık, Z. (2013). Ebeveyni ölen yetişkinlerde dini başa çıkma. (Yüksek lisans tezi, Marmara Üniversitesi, Sosyal Bilimler Enstitüsü, İstanbul). https://tez.yok.gov.tr/UlusalTezMerkezi/ adresinden edinilmiştir.

Janssen, Jacques, Joep de Hart and Christine den Draak, (1990). Praying as An Individualized Ritual”, Current Studies on Rituals-Perspectives for The Psychology of Religion. (Ed. Hans Günter Heimbrock and H. Barbara Boudewijnse). Rodopi Press, Amsterdam-Atlanta GA

Johnson, W. B., Devries, R. Ve Charles R Ridley (1994). The Comparative Efficacy of Christian and Secular Rational-Emotive Therapy with Christian Clients Journal of Psychology and Theology 22, 2 https://doi.org/10.1177/009164719402200206

Jung, C. G. (2001). Modern man in search of a soul. Psychology Press. Hail.

Khan, H.Z., Mughal, I., and Khan,Y. (2013). Combination of Psychological and Religious Intervention in Reducing Psychological Distress among University Students. Dialogue,8(3),261-272 Retrieved from www.qurtuba.edu.pk > thedialogue > Dialogue

Koç, M. (2008), Yetişkinlik döneminde dindarlık ile benlik kavramı değişkenleri arasındaki ilişki. (Doktora tezi, Uludağ Üniversitesi Sosyal Bilimler Enstitüsü, Bursa). https://tez.yok.gov.tr/ UlusalTezMerkezi/ adresinden edinilmiştir.

Koenig, H. G.,\&. Pritchett, J. (1998). Religion and psychotherapy. Handbook of religion and mental health (pp. 323-336). San Diego Academic Press, http://dx.doi.org/10.1016/B978-0124176454/50089-4

Koenig, H. G., McCullough, M. E., \& Larson, D. B. (2001). Handbook of religion and health. New York, NY: Oxford University Press.

Kutub, M. (1975). İslâm terbiye metodu ve ahlak sistemi. (A. Özek, Çev.) İstanbul: Hisar Yayınevi.

Malik R. (2018). Family Therapy and the Use ofQuranic Stories. Islamically Integrated Psychotherapy (Ed. Carrie York Al-Karam) Printed in the United States of America. Templeton Press

Marinier P. (1991). Dua üzerine düşünceler: psikofizyolojik sebepleri ve sonuçları, (S. Kılıç, Çev.). İzmir: Nil Yayınları.

Mccullough, M. E. - D. B. Larson (1999). Religion and depression: a review of the literature, Twin Research, C. 2 (2),126-136. http://dx.doi.org/10.1375/136905299320565997

McCulliss D. (2012). Bibliotherapy: historical and research perspectives. Journal of Poetry Therapy, 25, (1) 23-38. https://doi.org/10.1080/08893675.2012.654944

McKenna G., Hevey D., Martin E. (2010). Patients' and Providers Perspectives on Bibliotherapy in Primary Care", Clinical Psychology and Psychotherapy, 17(6), 497-509. Published online 8 February 2010 in Wiley Online Library (wileyonlinelibrary.com). http://dx.doi.org/10.1002/ cpp.679.

Mckinney J. Paul \& G. Kathleen Mckinney,(1999). Prayer in the lives of late adolescene, Journal of Adolescence, 22 (2), 279-290. https://doi.org/10.1006/jado.1999.0216

McMillen, P. S., Pehrsson D. E. (2004). Bibliotherapy for hospital patients. Journal of Hospital Librarianship, 4, (1), 73-81. http://dx.doi.org/10.1300/J186v04n01_07

Meadow, M. J. \& Kahoe, R. D. (1984). Psychology of religion: religion in individual lives. New York: Harper \& Row. 
Miller, W. R. \& Thoresen (2003). Spirituality, religion, and health: An emerging research field. American Psychologist, 58(1), 24-35. https://doi.org/10.1037/0003-066X.58.1.24

Moodley, R.,\& West, W. (Eds.). (2005). Integrating traditional healing into coun- seling and psychotherapy. Nevvbury Park, CA: Sage.

Muroff, J., Steketee, G., Bratiotis, C., Ross, A. (2012). Group cognitıve and behavioral therapy and bibliotherapy for hoardıng: a pilot trial, Depression And Anxiety, 29(7) ss.597-604. http://dx.doi. org/10.1002/da.21923.

Naylor, V. E. vd. (2010). Bibliotherapy as a treatment for depression in primary care, journal of clinical psychology in medical settings, 17, (3) 258-271. http://dx.doi.org/10.1007/s10880-0109207-2

Oman, D. ve Thoresen, C. E. (2013). Din ve maneviyat sağlı̆̆ etkiler mi? (Ö. Çetin, Çev.). R. F. Paloutzian ve C. L. Park (Ed.), Din ve maneviyat psikolojisi yeni yaklaşımlar ve uygulama alanları (s.295- 341). Ankara: Phoenix Yayınevi.

Özalp, N. (2000). Türk Mûsikîsi Tarihi, İstanbul, Milli Eğitim Basımevi.

Pargament, K. (1997). The psychology of religion and coping: Theory, Research, Practice. New York: The Guilford Press.

Pargament, K. I., H. Koenig ve L. Perez (2000). The many methods of religious coping: development and initial validation of the recope. Journal of Clinical Psychology. 56 (4), 519-543. http:// dx.doi.org/10.1002/(sici)1097-4679(200004)56:4<519::aid-jclp6>3.0.co;2-1

Pargament, K. (2007). Spiritually integrated psychotherapy: Uriderstanding and address- ing the sacred. New York, NY: Guilford Press.

Parlak, S. (2016). Manevi danışmanlığın gelişimi. [içinde] H. Ekşi \& Ç. Kaya (ed.), Manevi yönelimli psikoterapi ve psikolojik danışma (ss. 29-46). İstanbul: Kaknüs Yayınları.

Pécheur Se D. R. Edwards, K. (1984) A Comparison of secular and religious versions of cognitive therapy with depressed christian college students Journal of psychology and theology 12(1):45$54 \cdot \mathrm{http}: / / \mathrm{dx}$. doi.org/10.1002/da.22461

Peker, H. (2010). Dua, ibadet ve dinî törenler. din psikolojisi (Ed. Hökelekli, H.). Eskişehir: Anadolu Üniversitesi Yayını No: 2051 Açık öğretim fakültesi Yayını No: 1085 192-213.

Plante, T. (2009). Spiritual practices in psychotherapy: Thirteen tools for enhancmgpsycho- bgical health. Washington, DC: American Psychological Association. http://dx.doi.org/10.1037/ 11872-000

Plante, T. G. (1999). A collaborative relationship betvveen professional psychology and the Roman Catholic Church: A case example and suggested principles for success. Professional Psychology, Research and Practice, 30, 541-546. http://dx.doi.org/10.1037/ 0735-7028.30.6.541

Post, B.,\& Wade, N. (2009). Religion and spirituality in psychotherapy: A practice- friendly revievv of research. Journal of Clinical Psychology, 65, 131-146. 10.1002/jclp.20563

Propst, L. R. Ostrom, R., Watkins, P, Dean, T (1992). Comparative efficacy of religious and nonreligious cognitive-behavior therapy for the treatment of clinical depression in religious individuals Journal of Consulting and Clinical Psychology http://dx.doi.org/60(1):94-103

Rapee, R. M., Abbott, M. J.\& Lyneham, H. J. (2006). "Bibliotherapy for children with anxiety disorders using written materials for parents: a randomized controlled trial", Journal of Consulting and Clinical Psychology, 74, (3), 436-444. http://dx.doi.org/10.1037/0022-006X.74.3.436.

Robinson, L.C. (1994). Religious orientation in enduring marriage: An exploratory study. Review of Religious Research, 35(3), 207-218. http://dx.doi.org/10.2307/3511889 
Sezer, F. (2011). Öfke ve psikolojik belirtiler üzerine müziğin etkisi. Uluslararası İnsan Bilimleri Dergisi 8 (1), 1472-1493.

Shafranske, E. P. (2009). Spiritually oriented psychodynamic psychotherapy. Journal of Cli nical Psychology, 65(2), 147-157. http://dx.doi.org/10.1002/jclp.20565

Smith, T., Bartz, J., \& Richards, P. (2007). Outcomes of religious and spiritual adaptations to psychotherapy: A meta-analytic revievv. Psychotherapy Research, 17, 643-655. http://dx.doi. org/10.1080/10503300701250347

Smith, T. B. - E. McCullough- J. Poll (2003). Religiousness and Depression: Evidence for a Main Effect and The Moderating Influences of Stressful Life Events. Psychological Bulletin, 129, (4), 614-636. http://dx.doi.org/10.1037/0033-2909.129.4.614

Sohail, M.M. (2018). Belief in god's help during hepatitis C:A qualitative study on Muslim Patients in Pakistan. Journal of Religion and Health,1-18 http://dx.doi.org/10.1007/s10943-018-0700-5

Sperry, L.,\&. Shafranske, E. (2004). Spiritually oriented psychotherapy. Washington, DC: American Psychological Association.

Şengül, İ. (2002). Kıssa, Türkiye Diyanet Vakfi İslam Ansiklopedisi, 25, (1), 498-501,

Şengül, F. (2007). Dindarlık ve ruh sağglığı ilişkisi. (Yüksek lisans tezi, Marmara Üniversitesi Sosyal Bilimler Enstitüsü, İstanbul). https://tez.yok.gov.tr/UlusalTezMerkezi/ adresinden edinilmiştir.

Şirin, T. (2013). Bilişsel davranışçı psikoterapi yaklaşımıyla bütünleştirilmiş dini danışmanlık modeli, (Doktora tezi, Sakarya Üniversitesi Sosyal Bilimler Enstitüsü, Sakarya). https://tez.yok. gov.tr/UlusalTezMerkezi/ adresinden edinilmiştir.

Tan, S. Y. (2007). Use of prayer and Scripture in cognitive-behavioral therapy. Journal of Psychology and Christianity, 26, 101-111. Retrieved from https://pdfs.semanticscholar.org

Taylor, E. J. (2003). Prayer's Clinical Issues and Implications. Holistic Nurings Practice, XVII, (4), 179-188 http://dx.doi.org/10.1097/00004650-200307000-00004

Uçan, A. Vd. (2004). Müzik Öğretimi. Açıöğretim Fakültesi Okulöncesi Öğretmenliği Lisans Programı. Anadolu Üniversitesi Yayını: 1291

Van Lankveld, J. (1998). "Bibliotherapy İn The Treatment Of Sexual Dysfunctions: A MetaAnalysis." Journal of Consulting and Clinical Psychology. 66(4), 702-708. https://doi. org/10.1037/0022-006X.66.4.702

Walker, D. F., Gorsuch, R. L., Tan, S. Y., \& Otis, K. E. (2008). Use of religious and spiritual interventions in training in APA-accredited Christian psychology programs. Mental Health, Religion \& Culture, 11, 623-633. http://dx.doi.org/10.1080/13674670 701867648

Weld, C. \& Eriksen, K. (2007). Christian clients' preferences regarding prayer as a counseling intervention. Journal of Psychology and Theology, 35, 328-341. https://doi. org/10.1177/009164710703500405

West, W. (2000). Psychotherapy and spirituality: Crossing the line between therapy c religion. Thousand Oaks, CA: Sage. 